\title{
Probiotik Tidak Mempengaruhi Profil Sel Imun Adaptif pada Infeksi Escherichia coli
}

\section{Probiotic does not Influence the Profile of Adaptive Immune Cell in Escherichia coli Infection}

\author{
Astri Proborini ${ }^{1}$, Sumarno ${ }^{2}$, Sumakto ${ }^{3}$ \\ ${ }^{1}$ Program Studi IImu Biomedik Pasca Sarjana Fakultas Kedokteran Universitas Brawijaya Malang \\ ${ }^{2}$ Laboratorium Mikrobiologi Fakultas Kedokteran Universitas Brawijaya Malang \\ ${ }^{3}$ Laboratorium IImu Kesehatan Anak Rumah Sakit Umum Dr. Saiful Anwar Malang
}

\begin{abstract}
ABSTRAK
Probiotik diketahui memiliki peran potensial dalam manajemen beberapa kondisi patologis. Salah satu mekanisme penting dari sistem imun adalah konsep keseimbangan sitokin yang diperankan oleh sel Th1, Th2, Tregulator, dan sel Th17. Penelitian ini dilakukan untuk mengetahui pengaruh pemberian Lactobacillus rhamnosus dan L. acidophilus terhadap ekspresi sitokin Th1, Th2, Tregulator, Th17 pada sistem imun adaptif sistemik mencit yang terpapar oleh Lipopolisakarida (LPS) Escherichia coli. Tiga puluh dua ekor mencit BALB/c jantan dibagi menjadi 4 kelompok yaitu kelompok kontrol, LPS (mendapat LPS per sonde pada hari pertama), probiotik (mendapat probiotik per sonde selama 7 hari), LPS-Probiotik (mendapat LPS per sonde pada hari pertama, dilanjutkan probiotik per sonde selama 7 hari berikutnya). Pada hari ke-9 semua mencit dibunuh dan diambil sampel darahnya. Sel penghasil sitokin Th1 (IL-2, IFN- $)$ ), Th2 (IL-4, IL-5), Tregulator (IL10, TGF- $\beta$ ) dan Th17 (IL-17, IL-23) diperiksa dengan metode flowcytometri. Kelompok Probiotik, LPS dan LPS-Probiotik menunjukkan penurunan semua sel penghasil sitokin IL-2, IL-17, IL-23, IL-4, IL-10 dan TGF- $\beta$ yang berbeda bermakna dibanding kontrol, sedangkan kelompok LPS-Probiotik tidak menunjukkan perbedaan yang bermakna pada sel penghasil sitokin bila dibandingkan kelompok LPS. Pemberian probiotik pada penelitian ini tidak berpengaruh terhadap ekspresi sitokin sel Th1, Th2, Tregulator dan Th17 pada darah mencit yang terpapar LPS.
\end{abstract}

Kata Kunci: LPS, probiotik, respon imun adaptif sistemik

\begin{abstract}
Probiotic has a potential role in managing some pathologic condition. One of important mechanism in immune system is the balanced concept of cytokine performed by Th1, Th2, T-regulator and Th17 cells. This research was aimed to identify the effect of Lactobacillus rhamnosus and acidophilus to Th1, Th2, T-regulator and Th17 expression in adaptive immune systemic in Rat exposed with Lipopolysacharide (LPS) Escherichia coli. The 32 male rats BALB/c were divided into 4 which were: control, LPS for one day, probiotic for seven days, LPS (first day) with seven day probiotic. At 9 day, all subject were sacrified to collect the blood sample. The cell producing cytokines Th1 (IL-2, IFN- ), Th2 (IL-4, IL-5), Treg (IL-10, TGF-6) dan Th17 (IL-17, IL-23) were measured using flowcytometri. The probiotic, LPS and LPS+probiotic groups show significant reduction in all cells producing cytokines IL-2, IL-17, IL-23, IL-4, IL-10 and TGF-B compared to control group. There was no significant differences between LPS group and LPS-probiotic group. It can be concluded that the administration of probiotic does not influence the expression of cytokines Th1, Th2, Tregulator and Th17 cells in rat blood samples exposed with LPS.
\end{abstract}

Keywords: LPS, probiotic, adaptive immune systemic

Jurnal Kedokteran Brawijaya, Vol. 27, No. 4, Agustus 2013; Korespondensi: Astri Proborini. Program Studi Ilmu Biomedik Pasca Sarjana Fakultas Kedokteran Universitas Brawijaya Malang, Jl. Veteran Malang (0341)569117Email:ap rini@yahoo.com 


\section{PENDAHULUAN}

Diare akut masih merupakan penyebab utama morbiditas dan mortalitas anak di negara berkembang. Lebih dari 1,4 juta dari 9 juta anak di dunia meninggal oleh karena diare pada tahun 2008, dan lebih dari 50\% diantaranya berasal dari negara berkembang (1). Hasil Riskesdas 2007 menyebutkan bahwa diare merupakan penyebab kematian bayi tertinggi, yaitu $42 \%$, dan anak usia 1-4 tahun sebesar $25,2 \%$ (2). Penyebab diare umumnya adalah golongan virus, bakteri dan parasit. Di negara berkembang kuman patogen penyebab penting diare akut pada anak yaitu Rotavirus, Escherichia coli enterotoksigenik, Shigella dan Campylobacter jejuni (2). Dari beberapa intervensi untuk mengatasi diare, pemberian probiotik ternyata memiliki peran yang cukup potensial (3-5).

Probiotik dapat memberikan efek pro dan anti inflamasi, serta mengubah titik tangkap beberapa sitokin yang dihasilkan $C D 4^{+} T$ helper (Th), baik sel Th1 maupun Th2, dan menimbulkan mekanisme down-regulation pada mediator inflamasi (6). Sebagian besar probiotik dikelompokkan sebagai mikro organisme yang memproduksi asam laktat, yang umum digunakan meliputi tiga jenis bakteri, yakni, Lactobacillus, Bifidobacterium, dan Streptococcus $(3,7)$. Lactic Acid producing Bacteria (LAB) dapat menstimulasi respon imun baik spesifik maupun non spesifik (8).

Salah satu mekanisme penting dari sistem imun adalah konsep keseimbangan sitokin yang dihasilkan Th1, Th2, Tregulator dan Th17 (9). Ketidakseimbangan ini merupakan dasar terjadinya beberapa kondisi patologis antara lain alergi, ulcerative colitis, chron's disease, autoimun disease, Inflammatory Bowel Diseases (IBD) (10). Sitokin utama dari sel Th1 pada sistem imun mukosa saluran cerna adalah IFN- $\gamma$, IL-2, sel Th2 adalah IL-4, IL-5, IL-13, sel Tregulator adalah IL-10 dan TGF- $\beta$, serta sel Th17 adalah IL-17, IL-21, IL-22, IL-23(11).

Belum ada pembuktian secara langsung pengaruh pemberian probiotik terhadap ekspresi sitokin yang dihasilkan oleh sel Th1, Th2, Tregulator dan Th17 dari sistem imun adaptif sistemik pada infeksi yang disebabkan patogen pada saluran cerna, serta prosedur pemeriksaan ini tidak dapat dilakukan pada manusia, maka dipakai hewan coba mencit untuk mengetahui ekspresi sitokinsitokin yang diperiksa secara langsung dengan metode flowcytometry sebagai gambaran respon sekresi sel Th1, Th2, Tregulator dan Th17 pada darah.

Penelitian ini bertujuan untuk mengetahui pengaruh pemberian L. rhamnosus dan L. acidophilus terhadap sekresi sitokin Th1, Th2, Tregulator, Th17 di dalam darah mencit yang terpapar oleh LPS E. coli. Patogen dalam penelitian ini dipakai model endotoksin bakterial Lipopolisakarida (LPS) dengan dosis yang tidak mematikan namun tetap dapat menimbulkan respon yang diharapkan. Lipopolisakarida merupakan suatu endotoksin yang berasal dari bakteri gram negatif, merupakan stimulator kuat dari respon imun, dan sumber terjadinya suatu infeksi berat (12).

\section{METODE}

\section{Hewan Coba}

Hewan coba adalah mencit galur Mus musculus (Balb/c mice), yang berasal dari kandang hewan percobaan Pusat Veterinaria Farma Jalan Ahmad Yani Surabaya. Jenis kelamin mencit yang dipilih adalah jantan. Kriteria inklusi adalah usia mencit 10 s.d 12 minggu, berat badan 30 s.d 40 $\mathrm{g}$, dengan kondisi mencit sehat dan bebas penyakit (makan banyak, aktivitas baik, bulu tidak rontok). Hewan coba dieksklusi jika sakit dalam pengamatan, yang tampak dari perubahan perilaku hewan (perubahan pola makan/minum dan aktivitas) dan tanda-tanda klinis penting lainnya (penurunan berat badan, pola nafas, diare, muntah) dan sebagainya, atau mati dalam pengamatan.

Tabel 1. Karakteristik dasar mencit penelitian

\begin{tabular}{cccccc}
\hline & Kontrol & Probiotik & LPS & LPS-Probiotik & $\mathbf{p}$ \\
\hline $\begin{array}{c}\text { Jumlah } \\
\text { perkelompok (ekor) } \\
\text { Jenis Kelamin }\end{array}$ & 8 & 8 & 8 & 8 & - \\
Usia(minggu) & Jantan & Jantan & Jantan & Jantan- & \\
$\begin{array}{c}\text { RerataBBawal } \pm S D(g) \\
\text { RerataBBakhir } \pm S D(g)\end{array}$ & $34,0 \pm 4,47$ & $10-12$ & $10-12$ & $10-12-$ & \\
PutusUji & $37,25 \pm 4,17$ & $33,38 \pm 3,82$ & $32,75 \pm 3,65$ & $30,25 \pm 0,71$ & 0,164 \\
& Tidakada & Tidakada & Tidakada & Tidakada & - \\
\hline
\end{tabular}

Keterangan: BB: berat badan; nilai p signifikan jika $<0,05$

\section{Probiotik}

Probiotik yang dipakai per-kemasannya (sachet) didapatkan jumlah bakteri hidup (total viable count) dari jenis Mix bacteria dengan komposisi Lactobacillus rhamnosus R0011 1,9×109 cfu, dan Lactobacillus acidophilus R0052 0,1×109 cfu. Probiotik diberikan dengan dosis $10^{9} / \mathrm{kgBB} /$ hari sehingga setiap mencit akan mendapatkan dosis rata-rata $3 \times 10^{7} \mathrm{CFU}$. Probiotik ini akan dilarutkan dalam media D5\% sebanyak 0,5 cc dan diberikan melalui sonde lambung setiap hari (sekali sehari) selama 7 hari untuk kelompok Probiotik-LPS dan kelompok Probiotik.

\section{LPS}

LPS yang dipakai adalah LPS dari kuman Escherichia coli serotype 055:B5. LPS diberikan dengan dosis $250 \mu \mathrm{g} / \mathrm{kg} \mathrm{BB}$, sehingga setiap mencit akan mendapatkan dosis rata-rata 7,5 $\mu \mathrm{g}$. LPS ini akan diencerkan dengan larutan $\mathrm{NaCL} 0,9 \%$ dengan perbandingan 10:1, dan akan diberikan melalui sonde lambung, dilakukan sekali pada hari pertama penelitian untuk kelompok Probiotik-LPS dan kelompok LPS.

\section{Desain dan Prosedur Penelitian}

Penelitian ini adalah studi eksperimental dengan desain penelitian randomized post test only control group design yang dilakukan di Laboratorium Farmakologi dan Biomedik Fakultas Kedokteran Universitas Brawijaya Malang. Berdasarkan rumus Federer, dengan menggunakan 4 kelompok penelitian, sampel penelitian yang dibutuhkan adalah $\geq 6$ sampel per kelompok, dengan tambahan 2 sampel atas saran Komite Etik Kedokteran Hewan, sehingga total sebanyak 32 sampel penelitian diperoleh dengan 8 sampel per kelompok (Gambar 1$)$. 


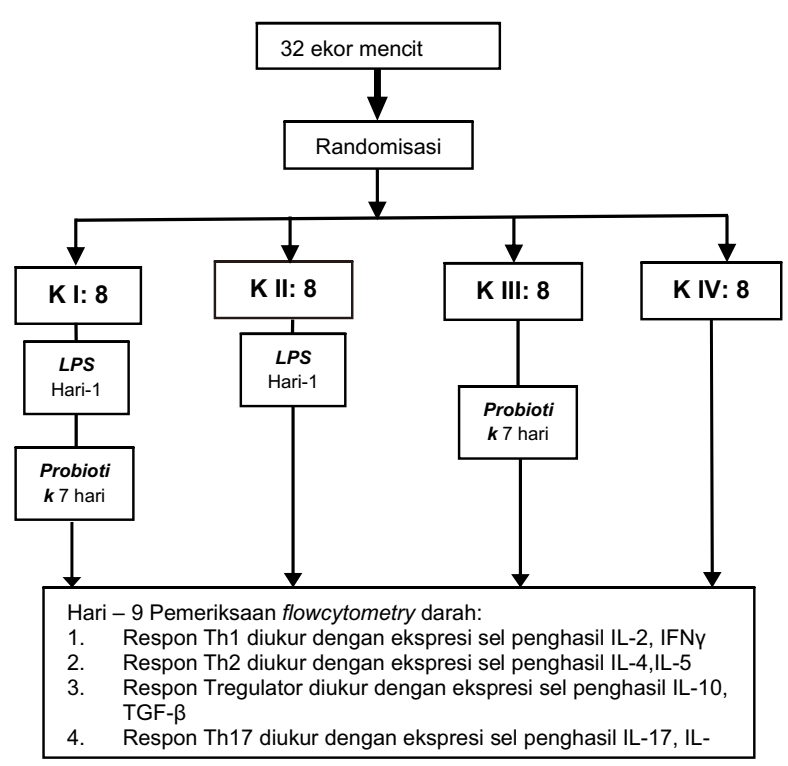

Gambar 1. Prosedur penelitian

\section{Pemeriksaan Flowcytometry}

Pemeriksaan Th1 menggunakan antibodi FITC anti-mouse CD4 nomor katalog 100406, PE anti-mouse IFNy nomor katalog 505808, PerCP/Cy5.5 anti-mouse IL-2 nomor katalog 503822. Pemeriksaan Th2 menggunakan antibodi FITC anti-mouse CD4 nomor katalog 100406, PE antimouse IL-5 nomor katalog 504304, Alexa Fluor ${ }^{\circledR}$ IL4 nomor katalog 504112. Pemeriksaan Tregulator menggunakan antibodi FITC anti-mouse CD4 nomor katalog 100406, PE anti-mouse IL-10 nomor katalog 505008, PerCP/Cy5.5 anti-human LAP (TGF- $\beta 1$ ) nomor katalog 341803. Pemeriksaan Th17 menggunakan antibodi FITC antimouse CD4 nomor katalog 100406, PE anti-mouse IL-23 p40 nomor katalog 505204, PerCP/Cy5.5 anti-mouse IL17A nomor katalog 506920. Penelitian ini mendapat persetujuan dari Komite Etik Penelitian Fakultas Kedokteran Universitas Brawijaya Malang.

\section{Analisis Statistik}

Analisis deskriptif disajikan untuk mengetahui gambaran hasil pengamatan berupa gambaran profil sitokin dari tiap-tiap kelompok. Data sekresi sitokin yang dihasilkan dinyatakan dalam mean, sedangkan untuk menganalisis pengaruh pemberian probiotik atau LPS terhadap ekspresi sitokin-sitokin yang dihasilkan oleh sel Th1, Th2, Tregulator dan Th17 pada darah mencit digunakan One WayANOVA.

\section{HASIL}

Karakteristik dasar dari sampel penelitian bersifat homogen karena persiapan sampel dirancang untuk penelitian eksperimental yang disesuaikan dengan kriteria inklusi.

\section{Profil Respon Imun Sel Th1,Th2, Tregulator dan Th17 Pasca Perlakuan}

Profil respon imun Th1, Th2, Tregulator dan Th17 pada kelompok kontrol menunjukkan bahwa IL-5 dari sel Th2 $(148,78 \pm$ SD12,15 sel/10.000 events) dan IL-10 dari sel Tregulator $(146,49 \pm$ SD25,24 sel/10.000 events) merupakan yang paling tinggi. IFN- $\gamma$ dari sel Th1 $(100,58 \pm S D 18,04$ sel/10.000 events) dan IL-23 dari sel Th17 (101,78 \pm SD16.09 sel/10.000 events) memiliki nilai yang hampir sama sedangkan sitokin IL-2 dari sel Th1

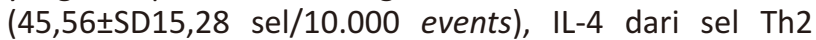
$(28,22 \pm$ SD 8,30 sel/10.000 events), TGF- $\beta$ dari sel Tregulator $(59,42 \pm$ SD5,37 sel/10.000 events) dan IL-17 dari sel Th17 (41,70 \pm SD2,96 sel/10.000 events) memiliki nilai lebih rendah daripada sitokin lainnya (Gambar 2).

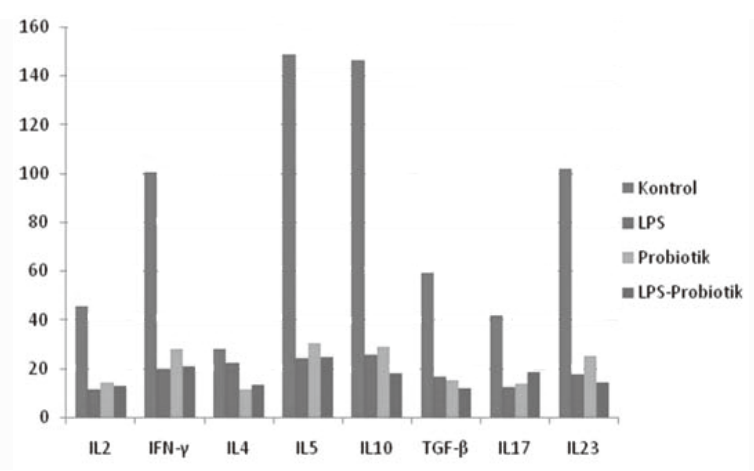

Gambar 2. Profil sitokin pada masing-masing kelompok perlakuan

Pemberian LPS kepada mencit yang sehat pada hari pertama perlakuan merupakan gambaran model infeksi bakteri gram negatif pada penelitian ini. Perlakuan tersebut memberikan efek penurunan semua sitokin yang disekresikan. Sitokin yang paling sedikit mengalami penurunan adalah sitokin IL-4 (dari sel Th2) yaitu $22,35 \pm 25,97 \mathrm{sel} / 10.000$ events. Sitokin yang lain masingmasing memiliki nilai sebagai berikut: IL-2 (dari sel Th1) 11,39 $\pm 0,39$ sel/10.000 events; IFN- $\gamma$ (dari sel Th1) 19,64 $\pm 1,38$ sel/10.000 events; IL-5 (dari sel Th2) 24,40 $\pm 3,08$ sel/10.000 events; IL-10 (dari sel Tregulator) 25,73 $\pm 3,49$ sel/10.000 events; TGF- $\beta$ (dari sel Tregulator) $16,56 \pm 1,93$ sel/10.000 events; IL-17 (dari sel Th17) $12,48 \pm 0,36 \mathrm{sel} / 10.000$ events serta IL-23 (dari sel Th17) $17,55 \pm 0,98 \mathrm{sel} / 10.000$ events (Gambar 2 ).

Pengaruh perlakuan pemberian probiotik kepada mencit sehat ditunjukkan oleh Gambar 2. Seperti halnya pada kelompok LPS, pemberian probiotik juga menyebabkan penurunan sekresi sitokin-sitokin dari sel Th1, Th2, Tregulator dan Th17 dengan nilai masing-masing sitokin adalah sebagai berikut: IL-2 14,39 $\pm 2,58$ sel/10.000 events; IFN- $\gamma \quad 27,95 \pm 5,68$ sel/10.000 events; IL-4 11,45 $\pm 0,80$ sel/10.000 events; IL-5 30,24 $\pm 5,32$ sel/10.000 events IL-10 $28,85 \pm 2,90$ sel/10.000 events; TGF- $\beta \quad 15,44 \pm 2,07$ sel/10.000 events; IL-17 13,83 $\pm 0,31$ sel/10.000 events serta IL-23 25,32 $\pm 0,50$ sel/10.000 events. Pada kelompok Probiotik ini nilai IL-5 adalah yang paling tinggi (Gambar 2).

Pada kelompok yang mendapatkan probiotik setelah paparan LPS pada hari pertama perlakuan (kelompok LPSprobiotik) ternyata didapatkan sekresi sitokin IL-5 adalah yang tertinggi $(24,75 \pm 5,64 \mathrm{sel} / 10.000$ events), selanjutnya adalah sitokin IFN- $\gamma(20,90 \pm 5,96$ sel/10.000 events). Sekresi sitokin IL-10 (18,18 $\pm 4,39$ sel/10.000 events) dan IL$17(18,42 \pm 12,23$ sel/10.000 events) hampir sama, sedangkan keempat sitokin lainnya memiliki nilai yang

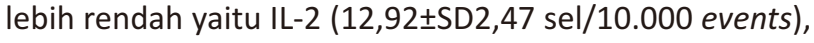


Tabel 1. Perbandingan nilai sel penghasil sitokin dari sel Th1, Th2, Tregulator dan Th17 antara kelompok LPS, probiotik dan LPS+probiotik dengan kelompok kontrol (sel/10.000 events)

\begin{tabular}{|c|c|c|c|c|c|c|c|c|}
\hline \multirow[b]{2}{*}{ Sel } & \multirow[b]{2}{*}{ Sitokin } & \multicolumn{7}{|c|}{ Kelompok } \\
\hline & & 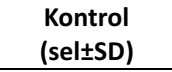 & $\begin{array}{c}\text { LPS } \\
\text { (sel } \pm S D)\end{array}$ & $p$ & $\begin{array}{l}\text { Probiotik } \\
\text { (sel } \pm S D)\end{array}$ & $p$ & $\begin{array}{l}\text { LPS+probiotik } \\
\text { (sel } \pm \text { SD) }\end{array}$ & $p$ \\
\hline \multirow{2}{*}{ Th1 } & IL-2 & $45,56 \pm 15,82$ & $11,39 \pm 0,40$ & $0,000^{*}$ & $14,39 \pm 2,58$ & $0,000^{*}$ & $12,92 \pm 2,47$ & $0,000^{*}$ \\
\hline & IFN- $\gamma$ & $100,58 \pm 18,04$ & $19,64 \pm 1,38$ & $0,000 *$ & $27,95 \pm 5,68$ & $0,000^{*}$ & $20,90 \pm 5,96$ & $0,000^{*}$ \\
\hline \multirow{2}{*}{ Th2 } & IL-4 & $28,23 \pm 8,30$ & $22,35 \pm 5,07$ & 0,388 & $11,45 \pm 0,80$ & 0,054 & $13,64 \pm 4,74$ & 0,071 \\
\hline & IL-5 & $148,79 \pm 12,15$ & $24,40 \pm 3,08$ & $0,000 *$ & $30,24 \pm 5,32$ & $0,000 *$ & $24,75 \pm 5,64$ & $0,000^{*}$ \\
\hline \multirow{2}{*}{ Treg } & IL-10 & $146,49 \pm 25,24$ & $25,73 \pm 3,49$ & $0,000 *$ & $28,85 \pm 2,90$ & $0,000^{*}$ & $18,18 \pm 4,39$ & $0,000^{*}$ \\
\hline & TGF- $\beta$ & $59,43 \pm 5,37$ & $16,56 \pm 1,93$ & $0,000 *$ & $15,44 \pm 2,07$ & $0,000^{*}$ & $11,98 \pm 0,93$ & $0,000^{*}$ \\
\hline \multirow{2}{*}{ Th17 } & IL-17 & $41,71 \pm 2,97$ & $12,48 \pm 0,36$ & $0,000 *$ & $13,83 \pm 0,31$ & $0,000 *$ & $18,42 \pm 2,23$ & $0,000^{*}$ \\
\hline & IL-23 & $101,78 \pm 16,10$ & $17,55 \pm 0,98$ & $0,000 *$ & $25,32 \pm 0,50$ & $0,000 *$ & $14,61 \pm 0,92$ & $0,000^{*}$ \\
\hline
\end{tabular}

Keterangan: *Perbedaan bermakna pada nilai $\mathrm{p} \leq 0,05$

IL-4 (13,64 $\pm 4,74$ sel/10.000 events), TGF- $\beta(11,98 \pm 0,93$

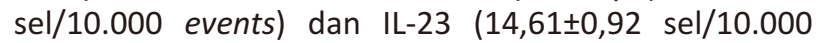
events) (Gambar 2).

\section{Perbandingan Nilai Sekresi Sitokin Th1, Th2, Tregulator} dan Th17 Darah antar Kelompok Perlakuan

Pemberian LPS pada mencit normal (kelompok LPS) pada hari pertama sebagai model infeksi memperlihatkan perubahan respon imun pada darah mencit yang berupa penurunan jumlah sekresi sitokin IL-2 dan IFN- $\gamma$ (sebagai respon imun sel Th1); sitokin IL-5 (sebagai respon imun sel Th2); sitokin TGF- $\beta$ dan IL-10 (sebagai respon imun sel Tregulator) serta sitokin IL-17 dan IL-23 (sebagai respon imun sel Th17) yang secara statistik bermakna bila dibandingkan kelompok kontrol. Penurunan sitokin IL-4 sebagai respon imun sel Th2 ternyata tidak bermakna dibandingkan kontrol (Tabel 1).

Pada kelompok yang mendapat perlakuan pemberian probiotik selama 7 hari (kelompok Probiotik) didapatkan sel penghasil sitokin IL-2 dan IFN- $\gamma$ (Th1); IL-5 (Th2); IL-10 dan TGF- $\beta$ (Tregulator) serta IL-17 dan IL-23 (Th17) lebih rendah dan berbeda bermakna secara statistik bila dibandingkan kelompok kontrol $(p<0,05)$. Akan tetapi sitokin IL-4 yang dihasilkan sel Th2 ternyata tidak berbeda secara statistik dengan kelompok kontrol (Tabel 2). Perbandingan sitokin IL-2 dan IFN- $\gamma$ (Th 1), IL-4 (Th2), IL-10 dan TGF- $\beta$ (Tregulator), serta IL-17 dan IL-23 (Th17) pada kelompok LPS+probiotik secara statistik berbeda signifikan dengan kelompok Kontrol. Kadar IL-4 (Th2) pada kelompok LPS tidak berbeda signifikan dengan kelompok Kontrol ( $p>0,05)$ (Tabel 1).

Untuk mengetahui pada aspek mana yang menyebabkan perbedaan antara pemberian probiotik dan LPS, maka dilakukan perbandingan antara kelompok Probiotik dan kelompok LPS. Dari perbandingan secara statistik ternyata tidak ada perbedaan yang bermakna dari sitokin-sitokin yang dihasilkan oleh sel Th1, Th2, Tregulator, dan Th17 pada kelompok Probiotik dan Kelompok LPS (Tabel 2).

Untuk mengetahui efek terapi dari probiotik terhadap respon imun Th1, Th2, Tregulator dan Th17 pada darah mencit yang dipapar patogen, dilakukan perbandingan antara kelompok LPS-Probiotik dengan kelompok LPS dan kelompok LPS-Probiotik dengan kontrol. Ternyata didapatkan bahwa perbandingan sitokin IL-2 dan IFN- $\gamma$ (Th1), IL-10 (Tregulator), serta IL-17 dan IL-23 (Th17), IL-4 dan IL-5 (Th2) pada kelompok LPS tidak berbeda signifikan dengan kelompok LPS+probiotik $(p>0,05)$. Hanya TGF- $\beta$ pada kelompok LPS yang berbeda signifikan dengan kelompok LPS+probiotik (Tabel 2).

Tabel 2. Perbandingan nilai sel penghasil sitokin dari sel Th1, Th2, Tregulator dan Th17 antara kelompok probiotik dan LPS+probiotik dengan kelompok LPS (sel/10.000 events)

\begin{tabular}{|c|c|c|c|c|c|c|}
\hline \multirow[b]{2}{*}{ Sel } & \multirow[b]{2}{*}{ Sitokin } & \multicolumn{5}{|c|}{ Kelompok } \\
\hline & & $\begin{array}{c}\text { LPS } \\
\text { (sel } \pm S D \text { ) }\end{array}$ & $\begin{array}{l}\text { Probiotik } \\
\text { (sel } \pm S D \text { ) }\end{array}$ & $p$ & $\begin{array}{l}\text { LPS+probiotik } \\
\text { (sel } \pm \text { SD) }\end{array}$ & k \\
\hline \multirow{2}{*}{ Th1 } & IL-2 & $11,39 \pm 0,40$ & $14,39 \pm 2,58$ & 0,467 & $12,92 \pm 2,47$ & 0,710 \\
\hline & IFN- $\gamma$ & $19,64 \pm 1,38$ & $27,95 \pm 5,68$ & 0,106 & $20,90 \pm 5,96$ & 0,802 \\
\hline \multirow{2}{*}{ Th2 } & IL-4 & $22,35 \pm 5,07$ & $11,45 \pm 0,80$ & 0,116 & $13,64 \pm 4,74$ & 0,205 \\
\hline & IL-5 & $24,40 \pm 3,08$ & $30,24 \pm 5,32$ & 0,124 & $24,75 \pm 5,64$ & 0,923 \\
\hline \multirow{2}{*}{ Treg } & IL-10 & $25,73 \pm 3,49$ & $28,85 \pm 2,90$ & 0,635 & $18,18 \pm 4,39$ & 0,256 \\
\hline & TGF- $\beta$ & $16,56 \pm 1,93$ & $15,44 \pm 2,07$ & 0,473 & $11,98 \pm 0,93$ & 0,006 \\
\hline \multirow{2}{*}{ Th17 } & IL-17 & $12,48 \pm 0,36$ & $13,83 \pm 0,31$ & 0,672 & $18,42 \pm 2,23$ & 0,070 \\
\hline & IL-23 & $17,55 \pm 0,98$ & $25,32 \pm 0,50$ & 0,065 & $14,61 \pm 0,92$ & 0,473 \\
\hline
\end{tabular}

Keterangan: *Perbedaan bermakna pada nilai p 0,05

\section{DISKUSI}

Penelitian ini dilakukan untuk membuktikan pengaruh pemberian probiotik sebagai terapi pada paparan LPS E.coli dengan indikator profil sitokin pro-inflamasi (Th1 dan Th17), anti-inflamasi (Th2) dan regulator (Tregulator). Oleh karena itu pemberian probiotik dilakukan pada hari kedua perlakuan setelah pemberian LPS pada hari pertama dengan dosis tidak letal namun mampu menginduksi respon imun.

Profil Respon Imun Th1, Th2, Tregulator dan Th17 pada Darah Mencit Normal

Sebelum mengetahui efek perlakuan terhadap respon imun mukosa usus mencit, maka profil imunologis dalam keadaan normal perlu diketahui. Dari hasil penelitian kami, profil imunologis mencit BALB/c normal ditinjau dari aspek keseimbangan sel Th1-Th17-Tregulator-Th2 menunjukkan suatu kondisi homeostasis, ditandai dengan tidak adanya perbedaan yang signifikan dari ekspresi sitokin-sitokin sel Th1, Th2, Tregulator dan Th17.

Iskandar, pada penelitiannya untuk mengetahui keseimbangan respon imun Th1 dan Th2 pada pemberian probiotik sebagai imunomodulator mendapatkan hasil yang sama, yaitu pada mencit normal terjadi suatu bias Th2 dengan sel penghasil Th2 mempunyai jumlah yang dominan diantara respon imun yang lain (13). Pada 
beberapa kondisi, mus musculus BALB/c dapat terjadi bias ke arah Th2, hal ini disebabkan karena adanya kerentanan strain ini terhadap Leishmania yang mengaktifkan CD4 untuk menghasilkan IL-4 dimana respon Th2 pada mencit BALB/C didominasi oleh IL-4 (14). Pada penelitian yang lain, didapatkan bias ke arah respon imun pro-inflamasi (Th17 dan Th1) yang tinggi pada mencit normal (mus musculus BALB/c) $(13,15)$.

Profil Respon Imun Th1, Th2, Tregulator dan Th17 pada Darah Mencityang Terpapar LPS E.coli

Kelompok LPS pada penelitian ini merupakan model yang menggambarkan suatu perjalanan alamiah bila individu mendapatkan paparan patogen. Pada penelitian ini kelompok yang mendapatkan perlakuan pemberian LPS pada hari pertama dan pemeriksaan respon imun dilakukan pada hari ke sembilan menunjukkan hasil bahwa pemberian LPS menyebabkan sitokin IL-5 (respon Th2) dan IL-10 (respon Tregulator) menjadi lebih dominan, diikuti penurunan pada sitokin yang lain yaitu (IL-2, IFN- $\gamma$, TGF- $\beta$, IL-17 dan IL-23). Kelompok LPS pada penelitian ini tidak menunjukkan perjalanan alamiah sebagaimana individu mendapatkan paparan patogen yang akan mengalami peningkatan respon pro-inflamasi. Dalam penelitian ini justru didapatkan penurunan dari semua sitokin yang diperiksa. Secara statistik, kelompok LPS memperlihatkan perubahan respon imun pada sitokin IL-2 dan IFN- $\gamma$ (sebagai respon imun Th1); IL-5 (sebagai respon imun Th2); TGF- $\beta$ (sebagai respon imun Tregulator); serta IL-17 dan IL-23 (sebagai respon imun Th17) yang berbeda signifikan dengan kelompok Kontrol $(p<0,05)$ dimana sitokin-sitokin tersebut mempunyai nilai yang lebih rendah. Sitokin IL-4 (sebagai respon imun Th2) pada kelompok LPS tidak berbeda signifikan dengan kelompok Kontrol ( $p>0,05)$, walaupun juga memiliki nilai yang lebih rendah dibandingkan kontrol. Dari sisi keseimbangan respon imun sel Th1-Th17-Tregulator-Th2 ternyata pada kelompok LPS ini sitokin-sitokin yang mewakili sel tersebut tidak berbeda secara signifikan yang berarti kondisi dalam keadaan setimbang.

Profil imunologis pada awal perjalanan alamiah paparan patogen (pemberian LPS) akan mengubah keseimbangan imunologis sel Th1-Tregulator-Th2-Th17, dimana akan terjadi peningkatan respon Th1 dan Th17, sedangkan respon Th2 dan Tregulator akan menurun (16). Hal serupa didapatkan pada penelitian Pulendran et al dan Iskandar yang menemukan bahwa respon imun terhadap paparan LPS akan menyebabkan peningkatan respon imun proinflamasi yaitu respon imun Th1 dan Th 17, serta penekanan pada respons imun Th2 $(13,16,17)$.

Hasil dari penelitian ini disebabkan karena pemeriksaan respon imun dilakukan delapan hari setelah pemberian LPS sehingga kemungkinan telah terjadi toleransi terhadap LPS. Pada paparan LPS, produksi maksimal respon imun Th1 (IL-2 dan IFN- - ) adalah 3-6 jam setelah paparan, kemudian akan menurun diikuti pergeseran ke arah respon imun Th2 (IL-4 dan IL-5) $(18,19)$. Pengaruh LPS terhadap respon imun dikatakan juga tergantung dari dosis yang diberikan, dimana pemberian dosis rendah yaitu $\pm 100 \mu \mathrm{g} / \mathrm{ml}$ maka respon imun pro-inflamasi (Th1 dan Th17) mencapai nilai maksimal pada 12 jam setelah paparan, sedangkan pada dosis tinggi $\pm 1000 \mu \mathrm{g} / \mathrm{ml}$ akan mencapai nilai maksimal pada 24 jam setelah paparan, kemudian respon akan menurun (20). Pada penelitian ini dosis LPS yang digunakan adalah $250 \mu \mathrm{g} / \mathrm{ml}$ dan pemeriksaan dilakukan setelah 8 hari paparan sehingga respon imun pro-inflamasi sudah tidak dominan lagi. Disamping itu pada kelompok LPS dalam penelitian ini tampaknya menunjukkan terjadinya proses penyembuhan yang ditandai oleh peningkatan IL-10 sehingga Th1 menurun, diikuti oleh penurunan TGF- $\beta$ dan IL-17(21).

Mekanisme lain yang mungkin terjadi adalah LPS langsung menginduksi Th2 khususnya IL-5 melalui aktivasi' NF-к $\beta$ yang kemudian menyebabkan regulasi positif terhadap GATA1 dan GATA2 sehingga meningkatkan produksi IL-5. $(22,23)$. Selain itu LPS dapat pula menginduksi respon imun Th2 melalui TLR4 (22).

Profil Respon Imun Th1, Th2, Tregulator dan Th17 pada darah mencit yang mendapat Probiotik

Banyak penelitian mengenai probiotik menyebutkan manfaat dalam memodulasi sistem imun baik secara in vitro, penelitian pada binatang coba, ataupun penelitian pada manusia (24). Hipotesis yang banyak berkembang saat ini mengatakan bahwa kemampuan probiotik dalam mengatur keseimbangan respon sel Th1-Th2 dan kemampuan imunoregulatornya terutama dimediasi oleh Tregulator. Proses regulasi ini sudah dimulai sejak dari awal proses imun dicetuskan, termasuk dalam mengatur proses signaling dari sel dendritik yang akan mempengaruhi diferensiasi dari sel Th0 menjadi sel Th1 ataupun Th2, maupun pembentukan sel Tregulator $(25,26)$.

Pemberian probiotik pada penelitian ini menyebabkan penurunan pada semua sitokin yang dihasilkan oleh sel Th1 (IFN- $\gamma$ dan IL-2), Th2 (IL-4 dan IL-5), Tregulator (IL-10 dan TGF- $\beta$ ) dan Th17 (IL-17 dan IL-23) dibandingkan kelompok kontrol dan secara statistik berbeda bermakna, kecuali untuk sitokin IL-4 (respon imun Th2). Sedangkan dari tinjauan keseimbangan respon imun sel Th1-Th17Tregulator-Th2 ternyata dengan pemberian probiotik, ekspresi sitokin-sitokin sel Th1, Th2, Tregulator, dan Th17 tidak berbeda bermakna yang berarti keseimbangan respon imun tersebut dapat dipertahankan sebagaimana pada kelompok kontrol.

Hasil penelitian ini serupa dengan penelitian oleh Pochard et al yang dalam penelitian in vitro-nya mendapati bahwa strain Lactobacillus yang berbeda menurunkan kadar sitokin IL-4 (sitokin Th2) dan meningkatkan produksi sitokin Th2, sehingga mengembalikan keseimbangan respon Th1/Th2 (27). Pochard et al pada penelitian mengenai efek strain Lactobacillus terhadap profil sekresi sitokin sel mononuklear darah tepi (peripheral blood mononuclear cells) pasca paparan dengan Staphylococcus enterotoxin $A$ atau alergen $D$ pteronyssinus mendapati bahwa pre-inkubasi sel mononuklear dengan strain lactic acid bacteria yang berbeda-beda (Lactobacillus plantarum, Lactobacillus lactus, Lactobacillus casei dan Lactobacillus rhamnosus) ternyata menghambat produksi sitokin IL-4 dan IL-5 (merupakan sitokin sel Th2) (27). Pasca paparan dengan bakteri E.coli (gram negatif) tidak menghambat sekresi sitokin Th2 (28).

Hasil beberapa penelitian lain menyebutkan bahwa pemberian L.rhamnosus pada orang sehat akan menurunkan produksi sitokin IL-2, IL-4 dan IL-10 (29). Pada mencit normal BALB/c yang diberi probiotik selama 20 hari, akan menyebabkan penekanan produksi sitokin Th1 (IL-2 dan IFN- $\gamma$ ), Th2 (IL-4), Th17 (IL-17) dan T-regulator (IL- 
10) pada sel lien maupun mesenteric lymphonodi dibandingkan pada kontrol normal $(28,30)$.

Hasil yang berbeda didapatkan pada penelitian yang lain bahwa pemberian L. rhamnosus HNOOI secara normal merupakan induktor yang baik bagi produksi IFN- $\gamma$ jika diberikan secara oral pada mencit selama sensitisasi alergen (untuk memperbaiki respon Th2), dilain sisi produksi IL-4 dan IL-5 juga meningkat $(28,30)$. Pada penelitian tentang pemberian $L$. rhamnosus pada orang sehat dan pada penderita Crohn's disease akan menurunkan produksi sitokin IL-2, IL-4 dan IL-10 $(29,31)$. Pemberian strain Lactobacillus menyebabkan penekanan pada respon imun Th1 dan Th17. Pemberian L. rhamnosus pada model alergi justru akan meningkatkan respon imun Th1 (32)

Profil dan Keseimbangan Respon Imun Th1, Th2, Tregulator dan Th17 pada Darah mencit yang mendapat Probiotik setelah terpapar LPSE.coli

Pengaruh probiotik setelah paparan LPS E.coli sebagai model terapi pada penelitian ini dapat dilihat pada kelompok LPS-Probiotik. Profil sitokin pada kelompok ini menunjukkan gambaran yang menyerupai kelompok LPS (Gambar 2). Dari analisis statistik ternyata ekspresi sitokin dari sel Th1 (IFN- $\gamma$ dan IL-2), Th2 (IL-4 dan IL-5), Tregulator (IL-10) dan Th17 (IL-17 dan IL-23) kedua kelompok tersebut (LPS-Probiotik dan LPS) tidak menunjukkan hasil yang berbeda bermakna. Berdasarkan analisis terhadap keseimbangan respon imun Th1-Th17-Tregulator-Th2 pada kelompok LPS-Probiotik diketahui bahwa ternyata respon imun dalam keadaan seimbang.

Hasil penelitian ini menunjukkan bahwa pemberian probiotik yang mengandung $L$. rhamnosus dan $L$. acidophillus pada mencit yang terpapar LPS E.coli tidak

\section{DAFTAR PUSTAKA}

1. Black RE, Cousens S, Johnson HL, et al. Child Health Epidemiology Reference Group of WHO and UNICEF: Global, Regional, and National Caused of Child Mortality in 2008: A Systematic Analysis. The Lancet. 2010; 375(9730): 1969-1987.

2. Subagyo B dan Santoso N. Diare Akut. Di dalam: Buku Ajar Gastroentero-Hepatologi IDAI. Jakarta: Badan Penerbit IDAl; 2010; hal. 87-118.

3. James T. Health-benefit Claims for Probiotic Products. Clinical Infectious Diseases. 2008; 46: S122-124.

4. Hajela N, Nair GB, and Ganguly NK. Are Probiotics a Feasible Intervention for Prevention of Diarrhoea in the Developing World? Gut Pathogen. 2010; 2: 2-5.

5. Wardlaw T, Salama P, Brocklehurst C, et al. Diarrhoea: Why Children are Still Dying and What Can be Done. The Lancet. 2010; 375: 870-872.

6. Saavedra J and Tschernia A. Human Studies with Probiotics and Prebiotics: Clinical Implications. British Journal of Nutrition. 2002; 87: 241-246.

7. Canani R, Cirillo P, Terrin G, et al. Probiotics for Treatment of Acute Diarrhea in Children: Randomized Clinical Trial of Five Different Preparations. British Medical Journal. 2007; 335: 340-345.

8. Freedman A and Lewis S. Review Article: The Use of Biotherapeutic Agents in the Preventsion and memberi pengaruh terapi. Pada penelitian ini kelompok LPS-Probiotik ternyata mengalami proses penyembuhan alami. Proses penyembuhan model mencit sakit akibat paparan E.coli yang kemudian mendapatkan probiotik $L$. rhamnosus dan L.acidophillus selama tujuh hari menunjukkan hasil yang sama dengan proses penyembuhan alami. Hal ini diketahui dari respon imun yang terjadi dengan profil dan tingkat yang hampir sama serta secara statistik tidak berbeda bermakna. Sebagaimana pada kelompok LPS, keseimbangan respon imun juga telah kembali dicapai pada kelompok LPSProbiotik.

Berdasarkan hasil penelitian ini ternyata hipotesis penelitian tidak terbukti. Profil ekspresi sitokin Th1, Th2, T regulator dan Th17 pada pemberian L.rhamnosus dan L.acidophilus pada mencit yang sebelumnya terpapar LPS E.coli ternyata tidak berbeda bermakna dengan ekspresi sitokin Th1, Th2, Tregulator, dan Th17 mencit yang terpapar LPSE.coli saja.

Kekurangan pada penelitian ini adalah tidak melakukan pemeriksaan respon imun pada waktu yang berbeda mengingat ekspresi sitokin tertentu dapat dipengaruhi waktu. Pada penelitian ini juga tidak menggunakan dosis LPS yang berbeda yang mungkin akan memberikan rangsangan respon imun lebih kuat. Kekurangan lain adalah tidak digunakannya induktor sitokin pro inflamasi yang poten seperti Lipid A yang merupakan komponen toksin dari LPS yang menentukan virulensi bakteri, yang dapat menginduksi respon imun lebih adekuat. Penelitian ini membuktikan bahwa pemberian probiotik tidak berpengaruh terhadap ekspresi sitokin sel Th1, Th2, Tregulator, dan Th17 pada darah mencit yang terpapar LPS E.coli.

Treatment of Gastrointestinal Disease. Alimentary Pharmacology and Therapeutics. 1998; 12: 807-822

9. Subijanto, Suparto P, Suhartono T, dan Judajana. Gangguan Sistem Imun Mukosa Intestinal. Surabaya: Divisi Gastroenterologi Lab/SMF IImu Kesehatan Anak RS dr Soetomo-FK UNAIR; 2003.

10. Judarwanto W. Imunologi Mukosa Saluran Cerna. (Online) 2008. http://alergianak.bogspot.com [diakses 10 Februari 2010].

11. Magrone T and Jirillo E. The Cytokine-mediate Network in Health and Disease with Special Reference to the Gut Immune System Regulation. Journal of Clinical Ligand Assay. 2009; 14: 350-359.

12. Alexander C and Rietschel E. Bacterial Lipopolysaccharides and Innate Immunity. Journal of Endotoxin Research. 2001; 7(3): 167-202.

13. Iskandar D. Pengaruh Pemberian Probiotik terhadap Keseimbangan Sel Th1, Th2 dan Treg pada Respon Imun Mukosa Usus. [Tesis]. Universitas Airlangga, Surabaya. 2009.

14. Mohr AJ, Leisewitz AL, Jacobson LS, et al. Effect of Early Enteral Nutrition on Intestinal Permeability, Intestinal Protein Loss, and Outcome in Dogs with Severe Parvoviral Enteritis. Journal of Veterinary Internal Medicine. 2003; 17: 791-798.

15. Pratiwi TA. Pengaruh Pemberian L.rhamnosus dan 
L.acidophilus terhadap Sekresi sitokin Th1, Th2, Treg, Th17 pada Mukosa Usus Mencit yang Terpapar Lipopolisakarida E.coli. [Tesis]. Universitas Brawijaya, Malang. 2010.

16. Sansonetti P and Di Santo J. Debugging How Bacteria Manipulate the Imune Response. Journal of Immunology. 2007:149-61

17. Pulendran B, Kumar P, Cutler C, Mohamadzadeh M, Dyke $\mathrm{T}$, and Banchereau J. Lipopolysaccahrides from Distinct Pathogens Induce Different Classes of Immune Responses In Vivo. The Journal of Immunology. 2001; 167: 5067-5076.

18. Mukherjee S, Chen L, Papadimos T, Huang S, Zuraw B, and Pan Z. LPS driven Th2 Cytokine Production in Macrophages is Regulated by Both MyD88 and TRAM. Journal of Biological Chemistry. 2009; 284(43): 29391-29398.

19. Lauw F, Hove T, Dekkers $P$, Jonge E, Deventser S, and Poll T. Reduced Th1, but not Th2, Cytokine Production by Lymphocytes after In Vivo Exposure of Healthy Subjects to Endotoxin. Infection and Immunity. 2000; 68: 1014-1018.

20. Larsson R, Rocksen D, Lilliehook B, Jonsson A, and Bucht A. Dose-dependent Activation of Lymphocytes in Endotoxin-induced Airway Inflammation. Infection and Immunity. 2000; 68: 6962-6969.

21. Couper K, Blount D, and Riley E. IL-10: The Master Regulator of Immunity to Infection. The Journal of Immunology. 2008; 180: 5771-5777.

22. Eisenbarth S, Piggot D, Huleatt J, Visintin I, Herrick C, and Bottomly K. Lipopolysaccharide-enhanced, Tolllike Receptor 4-dependent T Helper Cell Type 2 Responses to Inhaled Antigen. Journal of Experimental Medicine. 2002; 196: 1645-1651.

23. Min J, Park S, Rhim T, Park S, Jang A, and Uh S. LPS Induced Inhibition of IL-5 and Eotaxin-2 Production in Atopic Asthmatics. Clinical and Experimental Immunology. 2007; 147: 440-448.

24. Cross M, Ganner A, Teilab D, and MF L. Patterns of Cytokine Induction by Gram-positive and Gramnegative Probiotic Bacteria. Federation of European
Microbiological Societies Immunology and Medical Microbiology. 2004; 42: 173-180.

25. Perdigon G, Galdeano C, Valdez J, and Medici M. Interaction of Lactic Acid Bacteria with the Gut Immune System. European Journal of Clinical Nutrition. 2002; 56: 21-26.

26. Szajewska H, Ruszczynski M, and Radzikowski A. Probiotics in the Prevention of Antibiotic-Associated Diarrhea in Children: A Meta-Analysis of Randomized Controlled Trials. Journal of Pediatric Gastroenterology and Nutrition. 2006; 149: 367-372.

27. Pochard P, Gosset P, Grangette C, et al. Lactic Acid Bacteria Inhibit TH2 Cytokine Production by Mononuclear Cells from Allergic Patients. Journal of Allergy and Clinical Immunology. 2002; 110(4): 617623.

28. Cross ML. Microbes versus Microbes: Immune Signals Generated by Probiotic Lactobacilli and Their Role in Protection against Microbial Pathogens. Federation of European Microbiological Societies Immunology and Medical Microbiology. 2002; 34: 245-253.

29. Kekkonen R, Lummela N, Karjalainen H, Latvala S, Tynkkynen S, and Jarvenpaa S. Probiotics Intervention Has Strain Spesific Anti-inflammatory Effects in Healthy Adults. World Journal of Gastroenterology. 2008; 14: 2029-2036.

30. Delcenserie V, Martel D, Lamoureux M, Amiot J, Boutin $\mathrm{Y}$, and Roy D. Immunomodulatory Effects of Probiotics in the Intestinal Tract. Current Issues in Molecular Biology. 2008; 10: 37-54.

31. Braat H, Brande J, Tol E, Hommes D, Peppelenbosch M, and Deventer S. Lactobacillus rhamnosus Induces Peripheral Hyporesponsiveness in Stimulated CD4+ T Cells via Modulation of Dendritic Cell Function. American Journal of Clinical Nutrition. 2004; 80: 16181625.

32. Lavasani S, Dzhambazov B, Nouri M, Fak F, Buske S, and Molin G. A Novel Probiotic Mixture Exerts a Therapeutic Effect on Experimental Autoimmune Encephalomyelitis Mediated by IL-10 Producing Regulatory TCells. PloS ONE. 2010; 5(2): 1-11. 